\title{
Reassessment of Indigofera pratensis var. coriacea Domin and var. angustifoliola Domin (Fabaceae: Faboideae) with the recognition of a new species
}

\author{
Aniuska A. Kazandjian ${ }^{1}$ and Peter G. Wilson²
}

\begin{abstract}
${ }^{1}$ Tropical Plant Sciences, School of Tropical Biology, James Cook University, Townsville QLD 4811, Australia, and Fundación Instituto Botánico de Venezuela, Caracas 1010-A, Venezuela

${ }^{2}$ National Herbarium of New South Wales, Royal Botanic Gardens,

Sydney NSW 2000, Australia
\end{abstract}

\begin{abstract}
The two varieties of Indigofera pratensis described by Karel Domin are reassessed. Indigofera pratensis var. coriacea is distinct from the widespread Indigofera pratensis sens. str. in a number of reproductive and vegetative characters and is here raised to specific rank as Indigofera scabrella. Indigofera pratensis var. angustifoliola is judged to be an environmental or rare geographic variant of Indigofera pratensis sens. str. and not worthy of continued recognition. Lectotypes are designated for both names.
\end{abstract}

\section{Introduction}

The Indigofera pratensis complex is widespread in open habitats in forest, woodland and shrubland or in savanna. Plants are usually found as low to tall shrubs with purplish-pink flowers that are usually more than $10 \mathrm{~mm}$ long and borne in dense, showy axillary racemes. In eastern Queensland, its range extends from the northern part of Cape York (c. $\left.12^{\circ} 35^{\prime}\right)$ to just north of Brisbane (c. $\left.27^{\circ} 15^{\prime}\right)$ but there are also scattered populations in inland Queensland, particularly between Townsville and Hughenden and in the vicinity of Mount Isa, with a few records from the northeastern part of the Northern Territory. A survey of herbarium specimens of $I$. pratensis was carried out as part of a review of this complex (Kazandjian 2002) and revealed considerable variation such that some morphotypes in this complex are apparently distinct at species or subspecies level. The inland populations of the complex were largely unknown when Domin (1926) divided Indigofera pratensis into three varieties: I. pratensis var. typica (=I. pratensis var. pratensis), I. pratensis var. coriacea and I. pratensis var. angustifoliola. The two new varieties were described from limited material and distinguished primarily on leaflet characters. In the present paper, we reassess and lectotypify these infraspecific taxa. 


\section{Indigofera pratensis var. coriacea and Indigofera pratensis var. pratensis}

Domin (1926) distinguished variety coriacea as having fewer, smaller leaflets with a more coriaceous texture, somewhat prominent lateral venation but obscure reticulate venation. Indeed, he suggested that I. pratensis var. coriacea might possibly be treated as a new species ('vielleicht eine selbständige Art').

\section{Hairs}

Hairs in these two taxa can be divided into two types, here designated T1 and T2. The $\mathrm{T}$-shaped hairs are the most commonly encountered type in Indigofera and have been described as 'uniseriate macroform biramous hairs' often with \pm equal arms (Prabhakar et al. 1985, Schrire 1995). T1 hairs are 'appressed' following the definition proposed by Hewson (1988), that is, the angle of elevation above the surface is in the range $0^{\circ}-15^{\circ}$. T2 hairs have their arms ascending at angles greater than this, to around $45^{\circ}$, with arms straight. Indigofera pratensis var. pratensis has both kinds, with the T2 type less frequent but tending to have longer arms, while var. coriacea has hairs of the T1 type only (Fig. 1 c, f). Hair density on the leaflets varies somewhat between the two taxa. In I. pratensis var. pratensis the leaflets have sparser hairs and are usually markedly discolorous with the additional feature of rather conspicuous reticulate venation, particularly on the lower surface (Fig. 2 a, b), whereas in var. coriacea, the leaflets have moderately dense hairs on both surfaces and are more or less concolorous (Fig. 2 c, d).

\section{Stipules}

Stipules differ markedly in length between these two taxa (Fig. 1 b, e): they are triangular-linear and 5-12 mm long in var. pratensis, but deltate and 1.0-1.5(-2) mm long in var. coriacea. These length differences are parallelled in the inflorescences (Fig $1 \mathrm{a}, \mathrm{b}$ ) where the bracts match the stipules in shape and relative length, being $2-3 \mathrm{~mm}$ and c. $0.5 \mathrm{~mm}$ long, respectively. There is a similar contrast in the size and shape of the calyx teeth: in var. pratensis they are $0.9-1.5 \mathrm{~mm}$ long and acute, while in var. coriacea they are $0.5-0.9 \mathrm{~mm}$ long and obtuse.

\section{Inflorescence characters}

Overall inflorescence characters also differ. The inflorescences of $I$. pratensis var. pratensis appear to be denser than those of var. coriacea (Fig. $1 \mathrm{a}, \mathrm{d}$ ). This is due to two features, the spacing of flowers and the length of the pedicels. On the racemes, the flowers are not always equally spaced and are often in loose groups of two or three with a longer space between the groups. In this study, density of flowers was measured as the distance between adjacent recently opened flowers (or groups of flowers) and was found to be (4-) 5-8 $\mathrm{mm}$ in var. coriacea but only $2-3(-4) \mathrm{mm}$ in var. pratensis. Pedicel length is clearly distinct: only $1.5-2.5 \mathrm{~mm}$ in var. pratensis compared with $3-5(-7) \mathrm{mm}$ in var. coriacea.

Plants grown under standardised environmental conditions were also well separated using the same morphological criteria (Kazandjian 2002), confirming that these character variations are not environmentally induced. Furthermore, the measurable morphological differences between the two taxa are maintained even though their populations are (at least partially) sympatric. Indigofera pratensis var. coriacea has a restricted distribution to the west of the Atherton Tableland, primarily around Chillagoe and the Walsh River but extending to the Mount Surprise area, and 

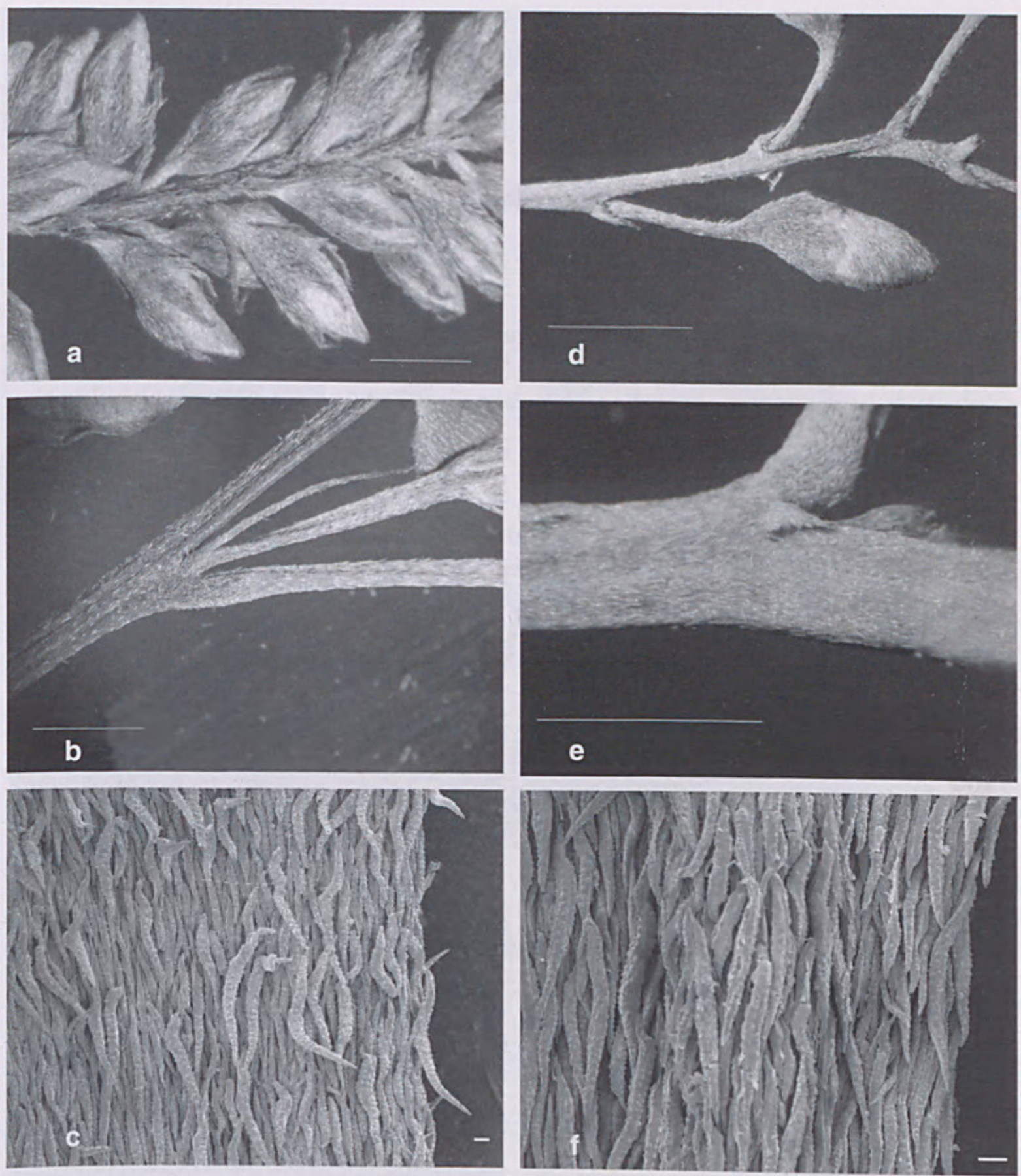

Fig. 1. Morphological characters. Indigofera pratensis var. pratensis. a, inflorescence showing long bracts, short pedicels and crowded flowers; b, stipule. c, SEM of stem showing T1- and T2-type hairs. Indigofera pratensis var. coriacea $\mathbf{d}$, inflorescence showing short bracts, long pedicels, short sepals and well-spaced flowers; e, stipule; f, SEM of stem showing T1-type hairs. (a,b from Puttock UNSW 14239; c from G. Wilson 5 (JCT); d,e from Kazandjian NSW 705606; f from Jackes 9954 (JCT). Scale bar: $a=3 \mathrm{~mm}, \mathrm{~b}=3 \mathrm{~mm}, \mathrm{c}=400 \mu \mathrm{m}, \mathrm{d}=3 \mathrm{~mm}, \mathrm{e}=6 \mathrm{~mm}, \mathrm{f}=500 \mu \mathrm{m}$. 
Indigofera pratensis var. pratensis has a wide range in eastern Queensland. The two taxa co-occur in the Chillagoe area without any sign of intergradation. Since there is no indication of any hybridisation between them, we therefore conclude, on both morphological and biological grounds, that Domin's var. coriacea should be recognised at specific rank.

Indigofera scabrella Kazandj. \& Peter G. Wilson, nom. et stat. nov.

Indigofera pratensis var. coriacea Domin, Biblioth. Bot. 89 (3): 191 (1926), non I. coriacea Aiton, 1789.

Type citation: 'Bei Chillagoe und besonders in den Savannenwäldern zwischen Crooked Creek und dem Walsh River (Domin II. 1910)' [near Chillagoe and particularly in the savanna woodland between Crooked Creek and the Walsh River].

Lectotype (designated here): Queensland: in xerodrymio inter riv. Crooked Creek et Walsh River, K. Domin 4515, Feb 1910 (PR 527226) (Fig. 3).

Residual syntype: Queensland: in xerodrymio inter fl. Walsh River et opp. Chillagoe, K. Domin 4514, Feb 1910 (PR 527225).
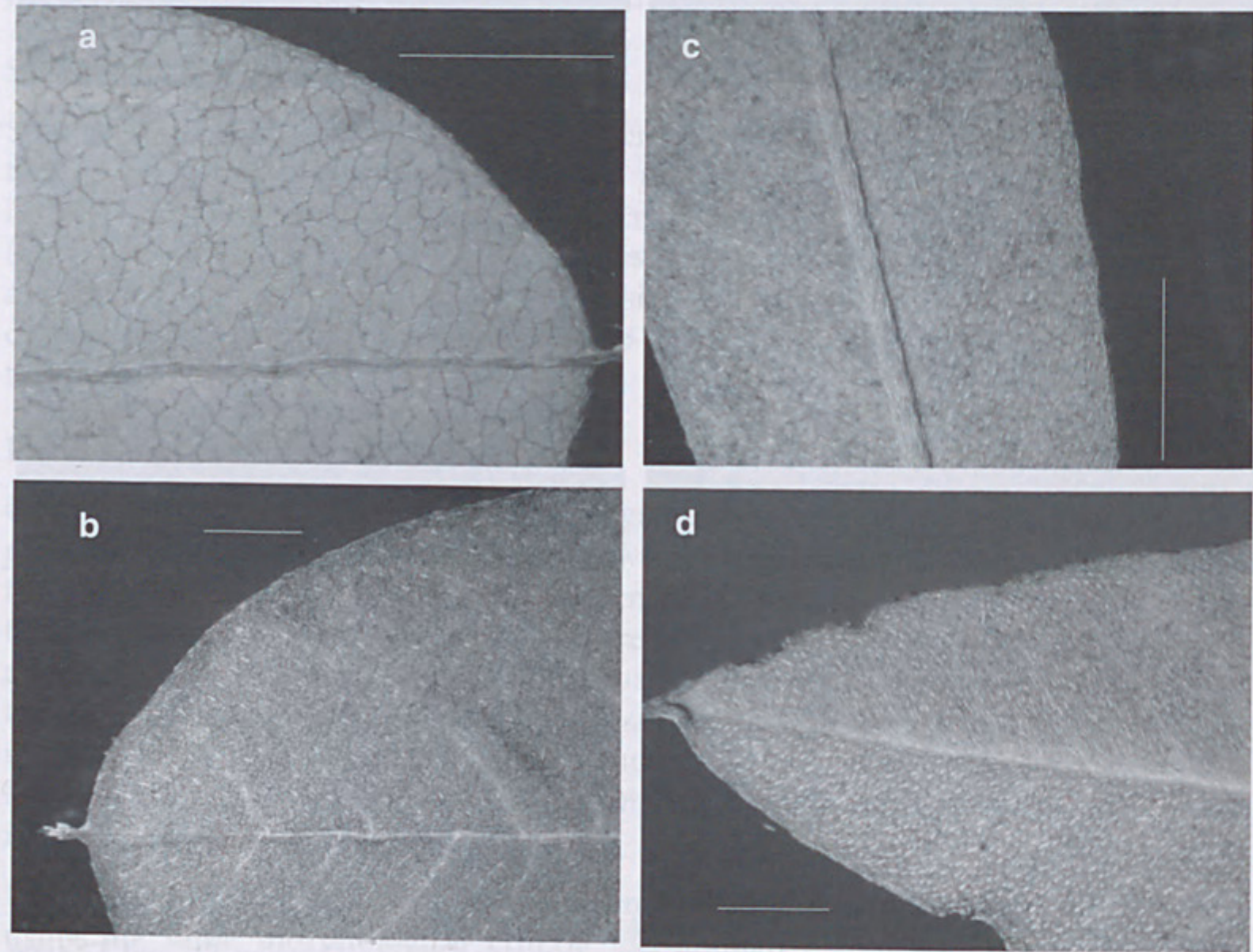

Fig. 2. Leaflet characters. Indigofera pratensis var. pratensis. a, undersurface showing conspicuous reticulum; b, upper surface. Indigofera pratensis var. coriacea. c, undersurface showing inconspicuous reticulum ; d, upper surface. (a,b from Puttock UNSW 14239; b,c from Kazandjian NSW 705606). Scale bars: $3 \mathrm{~mm}$. 


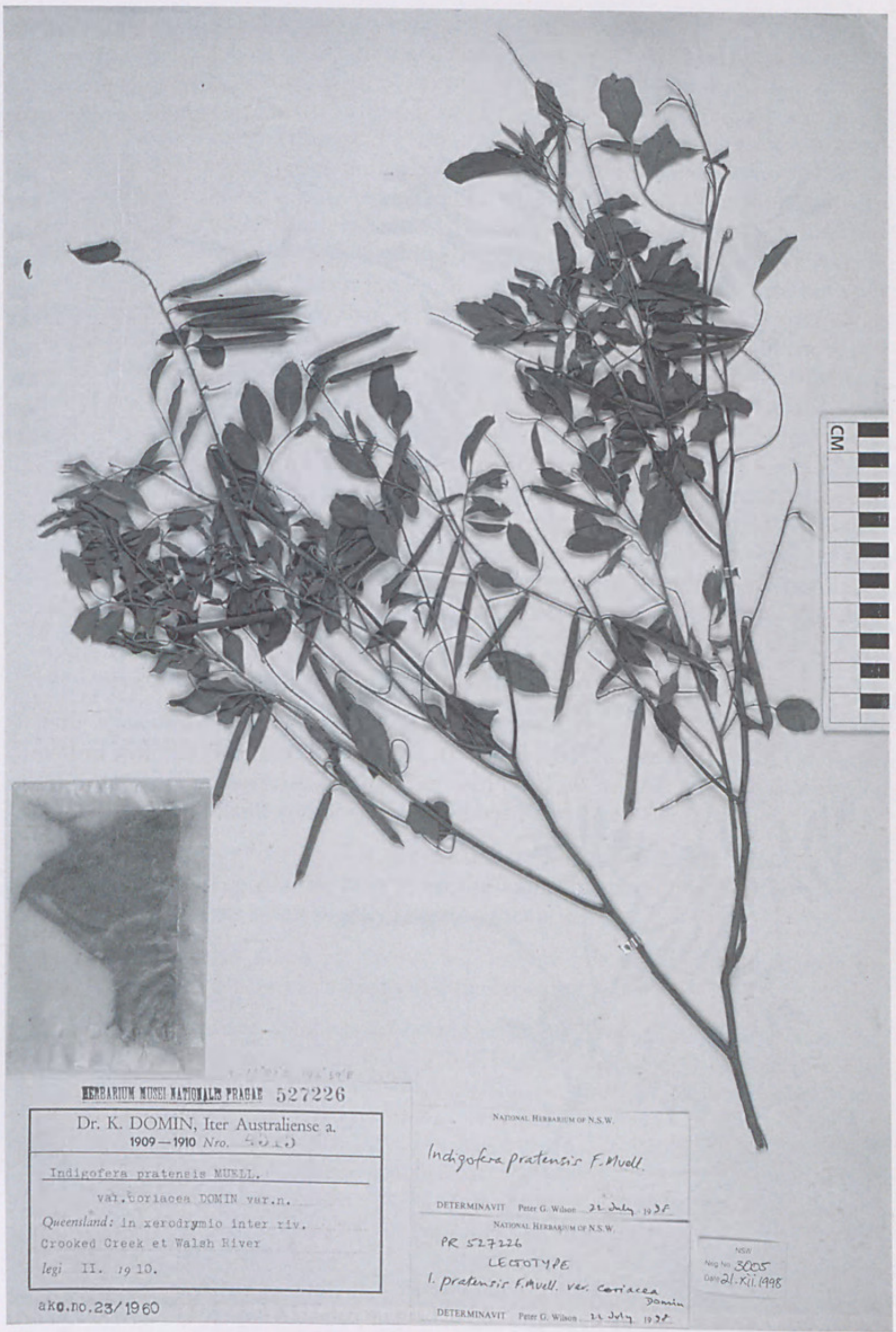

Fig. 3. Lectotype of Indigofera pratensis var. coriacea. 


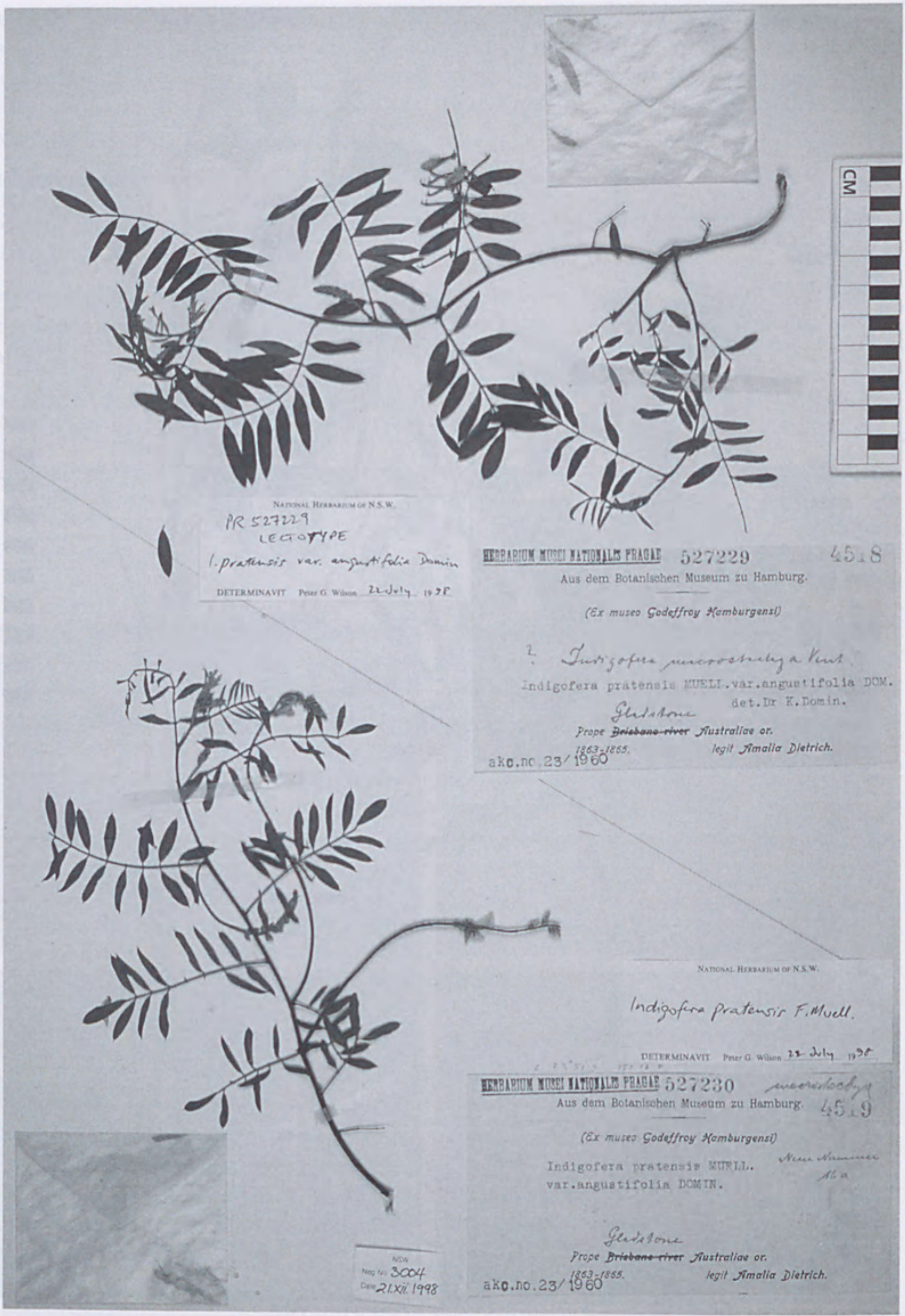

Fig. 4. Lectotype of Indigofera pratensis var. angustifoliola. 
Shrub or sub-shrub $0.5-0.8(-1.5) \mathrm{m}$ high. Young stems angular, densely covered with hyaline appressed T1-type biramous hairs. Leaves pinnate, $47-83 \mathrm{~mm}$ long, with (5-) 7-11 leaflets; stipules deltoid, 1.0-1.5(-2) mm long, (0.5-)0.7-0.9 mm wide; petiole c. 5-9 (-12) $\mathrm{mm}$ long; rachis furrowed. Leaflets coriaceous, green above and paler beneath; stipellae inconspicuous, to $0.7 \mathrm{~mm}$ long; lamina ovate to elliptical; the basal leaflets are (9-)11-23(-30) $\mathrm{mm}$, the lateral leaflets c. $12-25 \mathrm{~mm}$ and the apical leaflets 13-29 mm long; upper surface with sparse, appressed hairs, lower surface with moderately dense hairs; apex mucronate; secondary veins conspicuous but not prominent, the reticulum usually inconspicuous. Inflorescence a lax axillary raceme up to $150(-220) \mathrm{mm}$ long, much longer that the subtending leaf; distance between adjacent mature flowers more than $4 \mathrm{~mm}$. Bracts deltoid to narrowly triangular, 0.7-1.4 mm long. Flowers purple, $10-12 \mathrm{~mm}$ long; pedicels long, 3-5(-7) mm. Calyx 1.7-2 mm long; teeth $0.5-0.9 \mathrm{~mm}$ long, slightly shorter than the tube. Standard purple, 9-11 mm long, 5.5-7 $\mathrm{mm}$ wide, moderately hairy on the back, the apex obtuse-acute when the standard is fully expanded. Wings shorter than or equal to the standard, darker in colour towards the apex, 7-10.5 mm long, 2-3 mm wide. Keel as long as the standard, lateral pockets c. $1 \mathrm{~mm}$ long; hairs few and scattered at the base, becoming moderately dense towards the apex and margin. Staminal tube $7.5-8.5 \mathrm{~mm}$ long, purplish. Ovary appressed-hairy. Pods straight, cylindrical, $27-44 \mathrm{~mm}$ long, 2-3 mm wide, moderately densely pubescent; endocarp spotted. Seeds 6-10 per fruit, cylindrical to almost cubic, $1.5-2 \mathrm{~mm}$ long and wide; testa dark brown to light olive, the surface smooth to rough.

Phenology: flowers mostly in Summer; fruits mostly Autumn.

Distribution and habitat: This species is restricted to an area west of Atherton Tableland with the known distribution extending from "Nychum", NNW of Chillagoe, south to the Mount Surprise area (ie, between c. $16^{\circ} 50^{\prime}$ and $18^{\circ} 10^{\prime} \mathrm{S}$ ). It is recorded from savannah woodland and open forest on red or grey gravelly soils.

Notes: As the epithet 'coriacea' is pre-occupied, a new epithet is proposed. The proposed epithet, 'scabrella', is taken from the Latin meaning 'minutely scabrous', a reference to the leaflets being slightly rough to the touch.

Domin described this taxon as having 5-7 leaflets but leaves with 5 leaflets are uncommon, except for the early leaves of a new season's growth.

Other specimens examined: Queensland: Cook: $13 \mathrm{~km}$ from the Walsh River crossing on the road to Wrotham Park, Clarkson 4255, 14 Jan 1982 (BRI, CANB, NSW, UNSW); Mungana Red Hill, Cole 5114, 8 Aug 1963 (BRI); Petford-Chillagoe Rd, 11 km W of Almaden., Hacker 397, 16 July 1983 (BRI); $5 \mathrm{~km} \mathrm{~W}$ of Chillagoe, Jackes 9954, 9956, May 1999 (JCT, NSW); $22 \mathrm{~km} \mathrm{~W} \mathrm{of}$ Walsh river, Kazandjian AK0012Au, AK0013Au \& Dowe, 14 May 2001 (JCT, NSW); Nychum holding on Elizabeth Creek near homestead, Macdonald 1, 4 Dec 1970 (BRI, CANB, MEL, NSW); 29 km W of Mount Surprise, Puttock UNSW 13439, 20 Apr 1982 (NSW, UNSW); Lyndbrook, Etheridge Line, Towers s.n., 11 Apr 1960 (BRI); 0.8 km E of Mungana Yards, Wilson UNSW 13388 \& Puttock, 17 Apr 1982 (NSW, UNSW); 10.5 km E of Chillagoe, Wilson UNSW 13404 \& Puttock, 17 Apr 1982 (NSW, UNSW); 18.1 km E of Petford, Wilson UNSW 13407 \& Puttock, 17 Apr 1982 (NSW, UNSW); $73 \mathrm{~km}$ from Almaden on road to Mt. Surprise, $5 \mathrm{~km}$ past Bullock Creek Station turnoff, Forster 9635, 29 Jan 1992 (BRI, NSW).

Cultivated specimens: James Cook University, Townsville (seed ex Jackes 9954) Kazandjian s.n., 15 Jan 2002 (NSW 705631); James Cook University, Townsville (seed ex Wilson UNSW 13388 \& Puttock) Kazandjian s.n., 15 Jan 2002 (NSW 705606). 


\section{Indigofera pratensis var. angustifoliola}

The name I. pratensis var. angustifoliola Domin was based on specimens, collected near Gladstone by Amalie Dietrich, that were characterised by narrow leaflets $15-20 \mathrm{~mm}$ long and 2.75-3.75 mm wide. When Mueller (1860) described $I$. pratensis, from specimens collected in the Burdekin area, he gave the leaflet dimensions as $10-40 \mathrm{~mm}$ long and 6-13 mm wide. More recent measurements, over the geographic range of the Indigofera pratensis sens. str., indicate that the leaflet size is commonly in the range $10-30(-44) \mathrm{mm}$ long and 5-15(-24) $\mathrm{mm}$ wide (Wilson \& Rowe, unpublished data). When specimens that had been collected from the Queensland coast between $20^{\circ}$ and $25^{\circ} \mathrm{S}$ (ex BRI, CANB, MBA, MEL and NSW) were examined, only one had leaflets that matched Domin's description. This was a specimen (MEL586535) collected by Eugene Fitzalan in 1874 at Port Denison (Bowen), a considerable distance north of Gladstone. Apart from this, the only other specimen to approach the Dietrich collection is one of Robert Brown's found in the vicinity of Keppel Bay (near Rockhampton, just north of Gladstone); this appears to be a depauperate plant with leaflets $3-5.2(-6) \mathrm{mm}$ wide. A field trip to the Gladstone area did not locate any living plant with leaflets matching Domin's description, although plants of typical Indigofera pratensis were commonly encountered. These observations suggest that Dietrich (and Brown and Fitzalan) may have collected the specimens in a dry year when the size of the leaflets was affected by the availability of water. I. pratensis occurs in open Eucalyptus woodland in eastern Queensland where water and nutrient availability vary markedly from season to season. Field observations of other species suggest that features such as plant height, leaflet number and size, pedicel and petiolule length, and fruit size are likely to be affected by such environmental conditions. Hence, we judge var. angustifoliola to be an environmentally induced variant not worthy of recognition.

\section{Typification}

Domin listed two Dietrich collections in the protologue of this species, so lectotypification is required.

Indigofera pratensis var. angustifoliola Domin, Biblioth. Bot. 89 (3): 191 (1926)

Type citation: 'Gladstone, A. Dietrich s.n. und n. N. 16a, beide als I. macrophylla Venten. bestimmt.'

Lectotype (designated here): Queensland: Gladstone, A. Dietrich s.n. (PR 527229) Fig. 4. Isolectotype: HBG.

Residual syntype: Queensland: Gladstone, A. Dietrich 16a (PR 527230, HBG).

At PR, the two syntypes are mounted on a single sheet but with separate numbers; the lectotype is the upper specimen on the sheet. The typed label calls this taxon var. 'angustifolia' rather than angustifoliola, but there is no way of knowing if this was an error or if Domin changed his mind about the epithet when publishing the name. Also, Domin erred in the type citation since Dietrich had, in fact, determined the species as I. macrostachya Vent. (a synonym of the Himalayan species, Indigofera heterantha Wall. ex Brandis) not I. macrophylla Schumach. \& Thonn., an African species. 


\section{Acknowledgments}

This study represents a small part of a wider analysis of variation within the I. pratensis complex undertaken by the first author at James Cook University, Townsville. She is very appreciative of the financial support received from Fondo Nacional de Ciencia, Tecnología e Innovación (FONACIT) in Caracas, Venezuela. She is also grateful for the assistance and guidance given by Betsy R. Jackes (JCT), and thanks John Dowe and Juan Cruz for their help with locating and collecting specimens in the field. The second author is grateful to the Australian Biological Resources Study (ABRS) for grant funding that assisted in the earlier stages of this study. Both authors thank the relevant herbaria (PR, HBG, BRI, MBA, NSW, UNSW) for the loan of specimens.

\section{References}

Domin K (1926) Indigofera. Bibliotheca Botanica 89 (3): 741-746.

Hewson H (1988) Plant Indumentum. Australian Flora \& Fauna Series No. 9. (Australian Government Publishing Service: Canberra)

Kazandjian AA (2002) Systematics of the Indigofera pratensis Complex (Fabaceae): a Morphological and Molecular Approach. (Unpublished PhD thesis, James Cook University, Townsville)

Mueller F (1860) Essay on the plants collected by Mr. Eugene Fitzalan, during Lieut. Smith's expedition to the estuary of the Burdekin. (Government Printer: Melbourne)

Prabhakar M, Vijay Kumar BK, Ramayya N \& Leelavathi P (1985) Structure, distribution and taxonomic significance of trichomes in some Indigofera L. (Fabaceae). Proceedings of the Indian Acadademy of Science (Plant Science) 95: 309-314.

Schrire BD (1995) Evolution of the tribe Indigofereae (Leguminosae Papilionoideae). Pp. 161-244 in Crisp MD \& Doyle JJ (eds), Advances in Legume Systematics, vol. 7. (Royal Botanic Gardens: Kew)

Manuscript received 1 September 2004, accepted 12 May 2005 


\section{$2 \mathrm{BHL}$ Biodiversity Heritage Library}

Kazandjian Salazar, Aniuska and Wilson, Peter. 2005. "Reassessment of Indigofera pratensis var. coriacea Domin and var. angustifolia Domin (Fabaceae: Faboideae) with the recognition of a new species." Telopea: Journal of plant systematics 11(1), 43-51. https://doi.org/10.7751/telopea20055703.

View This Item Online: https://www.biodiversitylibrary.org/item/266381

DOI: https://doi.org/10.7751/telopea20055703

Permalink: https://www.biodiversitylibrary.org/partpdf/305714

\section{Holding Institution}

The Royal Botanic Gardens and Domain Trust, New South Wales, Australia

\section{Sponsored by}

Atlas of Living Australia

\section{Copyright \& Reuse}

Copyright Status: In copyright. Digitized with the permission of the rights holder.

Rights Holder: The Royal Botanic Gardens and Domain Trust, New South Wales, Australia License: http://creativecommons.org/licenses/by-nc-sa/4.0/

Rights: http://biodiversitylibrary.org/permissions

This document was created from content at the Biodiversity Heritage Library, the world's largest open access digital library for biodiversity literature and archives. Visit BHL at https://www.biodiversitylibrary.org. 